\title{
SELECTION OF LINEAGES, GENETIC PARAMETERS, AND CORRELATIONS BETWEEN SOYBEAN CHARACTERS
}

\author{
SELEÇÃO DE LINHAGENS, PARÂMETROS GENÉTICOS E CORRELAÇÕES ENTRE \\ CARACTERES EM SOJA
}

\begin{abstract}
Mariana Silva VIANNA ${ }^{1}$; Ana Paula Oliveira NOGUEIRA²; Osvaldo T. HAMAWAKI ${ }^{3}$; Larissa Barbosa de SOUSA ${ }^{4}$; Géssyca Ferreira GOMES ${ }^{5}$; Jacqueline Siqueira GLASENAPP ${ }^{6}$; Raphael Lemes HAMAWAKI ${ }^{7}$; Carolina Oliveira da SILVA ${ }^{8}$

1. Graduada em Biotecnologia - Universidade Federal de Uberlândia - UFU - Instituto de Genética e Bioquímica - INGEB, Uberlândia, MG, Brasil. Bolsista FAPEMIG. marianavianna11@gmail.com; 2. Professora, Doutora, Instituto de Genética e Bioquímica - Uberlândia, MG, Brasil; 3. Professor, Doutor, Instituto de Ciências Agrárias - ICIAG - Uberlândia, MG, Brasil; 4. Professora, Doutora, Instituto de Ciências Agrárias - ICIAG - UFU, Uberlândia, MG, Brasil; 5. Graduada em Biotecnologia, Instituto de Genética e Bioquímica - INGEB UFU, Uberlândia, MG, Brasil; 6. Pós doutoranda em Agronomia (Fitotecnia), Programa de Pós-Graduação em Agronomia - UFU, Uberlândia, MG, Brasil; 7. Doutorando em Melhoramento de Plantas, Southern Illinois University Carbondale, Illinois, EUA; 8. Mestranda em Agronomia, Programa de Pós-Graduação em Agronomia - UFU, Uberlândia, MG, Brasil.
\end{abstract}

\begin{abstract}
Soybean has great economic importance in the world accordingly, this legume has been exploited in breeding programs aiming to provide cultivars with extensive grain yield, tolerant to pests and diseases, and adapted to different soil and climatic conditions. Therefore, the objectives of this study were to evaluate genetic parameters and correlations between soybean traits to select lineages to increase yield and improve agronomic traits. Experiments were carried out on the Capim Branco farm, of the Federal University of Uberlândia, harvest in 2016/2017. Fifteen morph-agronomic traits were assessed on twenty-two genotypes in a randomized complete block design with three replicates. Agronomic traits related to cycle, height, number of nodes and total pods have shown coefficients of genotypic determination higher than $70 \%$. In addition, coefficients of variation of the number of days to the flowering and number of days to maturity were equal to $3.79 \%$ and $4.87 \%$, respectively, indicating high homogeneity of data and low random variation. Among evaluated traits, ten have presented the ratios between the coefficient of genetic variation $(\mathrm{CVg})$ and coefficient of environmental variation $(\mathrm{CVe})$ above one, demonstrating high success likelihood in the selection of these traits. Fifteen genotypes have presented grain yield above the national average of the 2016/2017 harvest, which was $2882 \mathrm{~kg} \mathrm{~h}^{-1}$. Significant phenotypic correlations between traits ranged from -0.49 to 0.89 , however genotype correlation was higher than the phenotypic ones, indicating that genetic factors have contributed more than the environmental factors. Traits related to cycle, height, and the number of nodes in the main stem have presented measures of $\mathrm{H}^{2}$ and $\mathrm{CVg} / \mathrm{CVe}$ with extensive magnitudes, evidencing the possibility of selection lineages having superior traits in the Soybean Breeding Program of the Federal University of Uberlândia. To increasing grain yield, the traits Number of pods of three grains and the Total number of pods were identified as appropriated to indirect selection based on the phenotypic and genotypic correlations. The 21P14, B2P1, B2P28, B1P33 and 2AP11 lineages stand out as superior genotypes to direct selection.
\end{abstract}

KEYWORDS: Glycine max. Plant breeding. Indirect selection.

\section{INTRODUCTION}

Soybean (Glycine max) has originated in Asia and through the years has become one of the main legumes cropped in the world. Due to the opening of new frontiers, to the development of new technologies of production in Brazilian conditions, to the genetic improvement of the species, availability 
of high grain yield cultivars, tolerance to pests and diseases. Also, well adapted cultivars to different soils and climatic conditions (NOGUEIRA; SEDIYAMA; GOMES, 2015).

Genetics and breeding research programs seek to develop new cultivars with agronomic superiority, high grain yield, wide adaptability, and stability. In addition, parents must be divergent among them and comprising favorable traits, ensuring larger genetic variability among the offspring. Therefore, some breeding programs seek to widen their soybean genetic basis to obtain more combinations on the breeding populations (BORÉM et al., 2015).

Breeding programs usually involve five main steps: parents' selection, crossing and obtaining segregating population advancement of generations through self-fertilization, agronomic performance tests, and selection of superior lineages. Several methods are applied to the improvement of crops aiming for the production of new cultivars, and the increase of grain yield is among the main objectives of these programs. Because it is a quantitative and complex trait, which results from the expression and association of different genetic components, it undergoes great environmental influence (NOGUEIRA, 2011).

The selection of superior genotypes is harder in either trait with low heritability or, traits of difficult assessment. For this purpose, correlations can be used as a tool for indirect selection of superior genotypes; studies of correlations between traits provide information about the changes occurring in one feature when the selection is made in the feature correlated to this (CRUZ; REGAZZI, CARNEIRO, 2012). The objective of this study was to evaluate genetic parameters and correlations between soybean traits, selecting lineages to increase yield and improve agronomic traits.

\section{MATERIAL AND METHODS}

Experiments were carried out on the Capim Branco farm (18 53'19' S; 48 $20^{\circ} 57^{\prime}$ ' W, $805 \mathrm{~m}$ altitude), of Federal University of Uberlândia, municipality of Uberlândia, Minas Gerais State, harvest 2016/2017. Twenty lineages developed by the Soybean Improvement Program of the Federal University of Uberlândia and two cultivars (CD 2737 and TMG 2158 IPro) were evaluated in a randomized complete block design with three replications on an area equal to $900 \mathrm{~m}^{2}$.

Four lines of $5 \mathrm{~m}$ in length and spaced $0.5 \mathrm{~m}$ apart made up each experimental plot; the two central rows $0.5 \mathrm{~m}$ at the row ends formed the useful area, resulting in $4 \mathrm{~m}^{2}$ for each plot. Soil preparation was performed as conventional; with one plowing and two harrowings. Previous to the sowing, the surface was grooved and fertilized according to soil analysis.

Regarding cultural practices were used herbicides to control pre and post emergence weeds, also complementing with manual weeding when necessary. Diseases and insect pests were controlled according to appropriate technical recommendations.

The agronomic traits were assessed according to the stages of crop development as Fehr and Caviness (1977) recommendations.

Evaluated traits were: number of day to the flowering (NDF); number of days to maturity (NDM); flowering plant height (APF); plant height at maturity (APM); number of nodes on main stem at the flowering (NNF); number of pods with one grain (NV1); two grains (NV2) and three grains (NV3); total number of pods per plant (NVT); number of pods showing aborted grains (NVCHOCHAS); and grain yield (PROD).

Data were submitted to individual variance analysis to assess phenotypic variability and estimate coefficients of genotypic determination. The data were grouped based on the $\mathrm{F}$ test at $5 \%$ of probability level. Subsequently, analyses of phenotypic and genotypic correlations were performed and statistical significances were tested by the $t$-test at the $5 \%$ probability level. All analyses were performed using the Computational Program in Genetics and Statistics (GENES) (CRUZ, 2016). 
Selection of lineages...

\section{RESULTS AND DISCUSSION}

Traits assessed have exhibited genetic
VIANNA, M. S. et al.

indicating the possibility of selection of superior lineages (Table 1).

variability at the $5 \%$ probability level by the $\mathrm{F}$ test,

Table 1. Phenotypic variability, genetic parameters and coefficient of variation of morpho-agronomic traits of 20 lines and 2 soybean cultivars sown in 2016/2017, Uberlândia - MG, Brazil.

\begin{tabular}{ccccc}
\hline Traits & QMG & CV $(\%)$ & $\begin{array}{c}\mathrm{H}^{2} \\
(\%)\end{array}$ & $\begin{array}{c}\text { CVg/ } \\
\text { CVe }\end{array}$ \\
\hline NDF & $14.30^{*}$ & 3.79 & 72.55 & 0.94 \\
APF & $423.01^{*}$ & 15.19 & 77.89 & 1.08 \\
NNF & $7.22^{*}$ & 8.71 & 86.25 & 1.44 \\
APV & $229.77^{*}$ & 21.75 & 85.71 & 1.41 \\
APM & $803.08^{*}$ & 9.94 & 87.92 & 1.56 \\
NDM & $444.53^{*}$ & 4.87 & 90.84 & 1.82 \\
NNPROD & $24.15^{*}$ & 26.09 & 48.54 & 0.56 \\
NNM & $17.73^{*}$ & 8.20 & 88.33 & 1.59 \\
NV1G & $6.35^{*}$ & 75.78 & 51.82 & 0.60 \\
NV2G & $258.80^{*}$ & 35.01 & 68.78 & 0.86 \\
NV3G & $135.78^{*}$ & 29.46 & 87.00 & 1.49 \\
NVCHOCH & $377.21^{*}$ & 40.09 & 86.84 & 1.48 \\
AS & & & & \\
NVCHOGR & $270.03^{*}$ & 38.56 & 87.41 & 1.52 \\
AO & & & & \\
NTVt & $841.95^{*}$ & 26.18 & 76.02 & 1.03 \\
PROD & 2016003. & 25.84 & 61.56 & 0.73 \\
& $71^{*}$ & & & \\
\hline
\end{tabular}

*: significant at 5\% probability, by $\mathrm{F}$ test; QMG: mean squares of genotypes; $\mathrm{CV}(\%)$ : coefficient of variation; $\mathrm{H}^{2}$ : coefficient of genotypic determination; $\mathrm{CVg}$ / CVe: ratio between coefficient of genetic variation (CVg) and coefficient of environmental variation (CVe); NDF: number of days for flowering, NDM: number of days to maturity; APF: flowering plant height, maturity plant height, APM: maturity plant height. NNF and NNM: Number of nodes on main stem at flowering and at maturity; NNPROD: number of productive nodes in the main stem; NV1G, NV2G and NV3G: number of pods with one, two and three grains; NVCHOCHAS: number of pods showing aborted grains; NVCHOGRAO: number of pods containing no grains; NTVt: sum of all plant pods; PROD: grain yield.

According to the morpho-agronomic analysis results the coefficient of variation ranged from 3.79\% to $75.78 \%$ regarding the number of days to the flowering and number of pods with one grain, respectively (Table 1). Sousa et al. (2013) evaluating agronomic traits in 71 soybean lineages have found a low CV to the number of days for flowering (5.04) due to environmental influence, thus it is less recommended selecting genotypes based on this attribute.
The coefficient of variation of $25.84 \%$ observed to grain yield in this study is justified because it is a trait subject to wide experimental interference. Machado (2017) evaluated the agronomic performance and genetic diversity of soybean lineages and cultivars in the same region and obtained coefficients of variation (CV) ranging between $2.13 \%$ to $56.50 \%$ for the number of days to maturity (NDM) and the number of pods with three grains (NV3), respectively. Higher CV values for production components are acceptable because these 
are quantitative traits largely influenced by the environment (LEITE et al., 2015) (DE SOUSA LEITE et al., 2016).

When genotype's effects are fixed, once they have been predetermined, the genotypic variation coefficient $\left(\mathrm{H}^{2}\right)$ expresses the proportion of phenotypic variability due to genetic causes (CRUZ; REGAZZI; CARNEIRO, 2012). In this study, $\mathrm{H}^{2}$ ranged from $48.54 \%$ to $90.84 \%$ for the number of productive nodes (NNPROD) and the number of days to maturity (NDM), respectively. Values of $\mathrm{H}^{2}$ above $70 \%$ are considered high, therefore NDF, APF, NNF, APV, APM, NDM, NNM, NV3G, NVCHOCHAS, NVCHOGRAO, and NTVt have shown high heritability according to our results, demonstrating that difference between genotypes is predominantly of genetic nature (Table 1).

Traits as number of productive nodes, number of pods with one and two grains, and yield, have shown $\mathrm{H}^{2}$ values lower than $70 \%$. These results might be justified by the fact that these are quantitative traits, which are driven by many genes and subject to higher environmental influences (HAMAWAKI et al, 2010).
VIANNA, M. S. et al.

The ratio between the coefficient of genetic variation and the coefficient of environmental variation is a useful quantity in plant breeding since it indicates a chance of success in the selection process. A trait is considered favorable to selection when values obtained by this ratio are equal or superior to one (CRUZ, REGAZZI, CARNEIRO, 2012). In this study, results obtained ranged from 0.56 to 1.82 for NNPRO and NDM, respectively (Table 1). Furthermore, APF, NNF, APV, APM, NDM, NNM, NV3G, NVCHOCHAS, NVCHOGRAO and NTVt traits have presented CVg / CVe results greater than 1 (Table 1).

Table 2 shows that NDF and NDM have separated genotypes into two groups. The NDF ranged from 49.00 to 58.00 for the B2P7 / B2P26 and B2P17 genotypes, respectively. The controls CD 2737 and TMG 2158 IPro were the earliest at 97 days. On the other hand, lineages of the UFU soybean program were late, with a total cycle of 123 to 142 in the genotypes B2P7 and B2P15. Genotypes B2P7, $\mathrm{B} 2 \mathrm{P} 20, \mathrm{~B} 2 \mathrm{P} 28, \mathrm{~B} 2 \mathrm{P} 38, \mathrm{~B} 1 \mathrm{P} 26$, and $\mathrm{B} 1 \mathrm{P} 33$ were found intermediate, with average taking from 123 to 131 days to reach maturity.

Table 2. Agronomic traits of lineages and soybean cultivars cropped in the 2016/2017 harvest, Uberlândia-MG, Brazil.

\begin{tabular}{cccccc}
\hline Genotypes & NDF (days) & NDM (days) & APF $(\mathrm{cm})$ & APM $(\mathrm{cm})$ & AIPV $(\mathrm{cm})$ \\
\hline B2P1 & $51.67 \mathrm{~b}$ & $138.33 \mathrm{a}$ & $66.07 \mathrm{a}$ & $116.20 \mathrm{a}$ & $24.13 \mathrm{c}$ \\
B2P7 & $49.00 \mathrm{~b}$ & $123.00 \mathrm{~b}$ & $58.30 \mathrm{a}$ & $102.70 \mathrm{~b}$ & $35.50 \mathrm{~b}$ \\
B2P8 & $51.67 \mathrm{~b}$ & $131.00 \mathrm{a}$ & $60.20 \mathrm{a}$ & $97.20 \mathrm{~b}$ & $26.27 \mathrm{c}$ \\
B2P11 & $57.00 \mathrm{a}$ & $140.50 \mathrm{a}$ & $68.80 \mathrm{a}$ & $116.40 \mathrm{a}$ & $47.80 \mathrm{a}$ \\
B2P12 & $53.00 \mathrm{~b}$ & $134.00 \mathrm{a}$ & $77.87 \mathrm{a}$ & $103.40 \mathrm{~b}$ & $23.40 \mathrm{c}$ \\
B2P13 & $51.00 \mathrm{~b}$ & $128.50 \mathrm{a}$ & $59.40 \mathrm{a}$ & $71.40 \mathrm{c}$ & $13.70 \mathrm{~d}$ \\
B2P14 & $53.00 \mathrm{~b}$ & $138.33 \mathrm{a}$ & $74.00 \mathrm{a}$ & $105.93 \mathrm{~b}$ & $36.47 \mathrm{~b}$ \\
B2P15 & $51.67 \mathrm{~b}$ & $142.67 \mathrm{a}$ & $66.73 \mathrm{a}$ & $118.87 \mathrm{a}$ & $30.40 \mathrm{~b}$ \\
B2P17 & $58.33 \mathrm{a}$ & $138.33 \mathrm{a}$ & $81.93 \mathrm{a}$ & $115.33 \mathrm{a}$ & $33.67 \mathrm{~b}$ \\
B2P20 & $50.33 \mathrm{~b}$ & $130.33 \mathrm{~b}$ & $57.53 \mathrm{a}$ & $103.20 \mathrm{~b}$ & $32.67 \mathrm{~b}$ \\
B2P26 & $49.00 \mathrm{~b}$ & $140.50 \mathrm{a}$ & $52.70 \mathrm{~b}$ & $78.90 \mathrm{c}$ & $23.50 \mathrm{c}$ \\
B2P27 & $51.00 \mathrm{~b}$ & $140.50 \mathrm{a}$ & $64.40 \mathrm{a}$ & $86.80 \mathrm{c}$ & $24.33 \mathrm{c}$ \\
B2P28 & $53.00 \mathrm{~b}$ & $128.50 \mathrm{~b}$ & $70.30 \mathrm{a}$ & $111.10 \mathrm{a}$ & $18.70 \mathrm{~d}$ \\
B2P33 & $51.67 \mathrm{~b}$ & $134.67 \mathrm{a}$ & $71.67 \mathrm{a}$ & $87.53 \mathrm{c}$ & $26.80 \mathrm{c}$ \\
B2P38 & $53.00 \mathrm{~b}$ & $130.33 \mathrm{~b}$ & $79.47 \mathrm{a}$ & $112.53 \mathrm{a}$ & $34.67 \mathrm{~b}$
\end{tabular}


Selection of lineages...

VIANNA, M. S. et al.

$\begin{array}{cccccc}\text { B1P26 } & 53.00 \mathrm{~b} & 130.33 \mathrm{~b} & 62.87 \mathrm{a} & 114.13 \mathrm{a} & 24.80 \mathrm{c} \\ \text { B1P33 } & 50.33 \mathrm{~b} & 126.67 \mathrm{~b} & 57.20 \mathrm{a} & 100.13 \mathrm{~b} & 31.33 \mathrm{~b} \\ \text { CD2737 } & 50.67 \mathrm{~b} & 97.00 \mathrm{c} & 41.50 \mathrm{c} & 83.00 \mathrm{c} & 13.13 \mathrm{~d} \\ \text { TMG 2158 } & 53.00 \mathrm{~b} & 97.00 \mathrm{c} & 30.47 \mathrm{c} & 64.40 \mathrm{c} & 13.20 \mathrm{~d} \\ \text { IPro } & 53.00 \mathrm{~b} & 134.00 \mathrm{a} & 61.90 \mathrm{a} & 75.60 \mathrm{c} & 15.90 \mathrm{~d} \\ \text { 2LP14 } & 51.50 \mathrm{~b} & 140.50 \mathrm{a} & 71.20 \mathrm{a} & 114.70 \mathrm{a} & 29.50 \mathrm{~b} \\ \text { 2AP11 } & 53.00 \mathrm{~b} & 134.67 \mathrm{a} & 66.20 \mathrm{a} & 101.60 \mathrm{~b} & 19.67 \mathrm{~d} \\ \text { P19 16c } & & \end{array}$

Means followed by the same letter belong to the same group by the Scott Knott test at 5\% probability. NDF and NDM: Number of days for flowering and maturity; APF and APM: Plant height at flowering and at maturity; and AIPV: First pod insertion height.

Plant height at flowering has divided genotypes into three groups, however, most genotypes have shown averages ranging from 57.20 to $81.93 \mathrm{~cm}$ (Table 2). The average plant height at maturity also has separated assessed genotypes in three groups, the smallest plants have comprised heights between 64 and $87 \mathrm{~cm}$, intermediate plants between 100 and 105 $\mathrm{cm}$, and the tallest plants from 112 to $118 \mathrm{~cm}$.

Both plant height at flowering and plant height at maturity are relevant traits, taller plants are more prone to lodging than smaller ones, and plants higher than $100 \mathrm{~cm}$ decrease the efficiency of the mechanized harvest. Ideal heights in the soybean cropping range from 40 to $90 \mathrm{~cm}$ (NOGUEIRA et al., 2009; SEDIYAMA et al., 2015).

First pod insertion height is another important trait during the process of soybean lineage selection. According to Sediyama (2013), to avoid losses and guarantee maximum efficiency in harvesting, the ideal height of insertion to the first pod lay between 10 and $15 \mathrm{~cm}$; the insertion of the first pod determines the height adjustment of the harvester-cutting bar. In this study, the average values for APV ranged from 13.13 to $47.8 \mathrm{~cm}$ regarding the genotypes CD 2737 and B2P11, respectively. These results may be higher than the ideal height found in other studies, due to climatic and environmental factors that this experiment has been submitted.

Genotypes B1P13, B2P28, CD2737, TMG 2158 IPro, 2LP14, and P19 16c presented lower estimates of AIPV, varying from 13.13 to 19.67 (Table 2). These results are similar to those found by Dornelas et al. (2011), in which the average height of the insertion of the first pod oscillated from 9 to $16 \mathrm{~cm}$ in 22 soybean lineages. Higher values of insertion of the first pod may be due to either some type of stress that has caused abortion of lower flowers or plant genetics. In this work, we have used in the F8 generation in the same lineages used by Souza (2013) on his study in the F6 generation, which also presented high insertion values of the first pod.

The number of nodes in the main stem is an important feature for lineage selection because it is directly correlated to grain yield (SEDIYAMA; SILVA; BORÉM, 2015). The results in Table 3 showed the number of nodes in flowering and the number of nodes at maturity ranging from 9.80 to 14.07 and 13.40 to 24.67 , respectively. According to Sediyama; Silva and Borém (2015), an ideal soybean plant must have around 18 nodes, therefore, the genotypes P19 16c, B2P33, B2P8, 2AP11, B2P38, $\mathrm{B} 1 \mathrm{P} 33, \mathrm{~B} 2 \mathrm{P} 1, \mathrm{~B} 2 \mathrm{P} 14$, and $\mathrm{B} 2 \mathrm{P} 17$ were found promising to breeding.

Although results presented in Table 1 indicate the existence of genetic variability regarding NNPROD, Scott Knott test results did not allow the division of genotypes into more than one group (Table $3)$. 
Table 3. The number of nodes in the main stem, number of nodes at flowering and maturity, and number of productive nodes in cultivated soybean lineages and cultivars in the 2016/2017 harvest, Uberlândia-MG, Brazil.

\begin{tabular}{cccc}
\hline Genotypes & NNF & NNM & NNPROD \\
\hline B2P1 & $10.87 \mathrm{~b}$ & $18.33 \mathrm{~b}$ & $14.47 \mathrm{a}$ \\
B2P7 & $9.80 \mathrm{~b}$ & $16.80 \mathrm{c}$ & $12.60 \mathrm{a}$ \\
B2P8 & $11.07 \mathrm{~b}$ & $16.07 \mathrm{c}$ & $12.67 \mathrm{a}$ \\
B2P11 & $12.70 \mathrm{a}$ & $18.90 \mathrm{~b}$ & $11.90 \mathrm{a}$ \\
B2P12 & $11.73 \mathrm{a}$ & $16.67 \mathrm{c}$ & $11.07 \mathrm{a}$ \\
B2P13 & $10.50 \mathrm{~b}$ & $13.40 \mathrm{~d}$ & $11.00 \mathrm{a}$ \\
B2P14 & $11.67 \mathrm{a}$ & $18.07 \mathrm{~b}$ & $12.20 \mathrm{a}$ \\
B2P15 & $12.00 \mathrm{a}$ & $24.67 \mathrm{a}$ & $17.93 \mathrm{a}$ \\
B2P17 & $14.07 \mathrm{a}$ & $17.93 \mathrm{~b}$ & $12.00 \mathrm{a}$ \\
B2P20 & $10.47 \mathrm{~b}$ & $19.13 \mathrm{~b}$ & $14.13 \mathrm{a}$ \\
B2P26 & $10.40 \mathrm{~b}$ & $14.80 \mathrm{~d}$ & $9.40 \mathrm{a}$ \\
B2P27 & $11.00 \mathrm{~b}$ & $15.43 \mathrm{c}$ & $11.70 \mathrm{a}$ \\
B2P28 & $13.00 \mathrm{a}$ & $20.10 \mathrm{~b}$ & $15.80 \mathrm{a}$ \\
B2P33 & $12.20 \mathrm{a}$ & $17.00 \mathrm{c}$ & $12.73 \mathrm{a}$ \\
B2P38 & $13.53 \mathrm{a}$ & $18.40 \mathrm{~b}$ & $13.20 \mathrm{a}$ \\
B1P26 & $11.93 \mathrm{a}$ & $20.00 \mathrm{~b}$ & $12.93 \mathrm{a}$ \\
B1P33 & $10.93 \mathrm{~b}$ & $18.47 \mathrm{~b}$ & $23.27 \mathrm{a}$ \\
CD2737 & $7.93 \mathrm{c}$ & $16.93 \mathrm{c}$ & $15.67 \mathrm{a}$ \\
TMG 2158 IPro & $8.13 \mathrm{c}$ & $13.67 \mathrm{~d}$ & $13.33 \mathrm{a}$ \\
2LP14 & $12.70 \mathrm{a}$ & $15.60 \mathrm{c}$ & $12.80 \mathrm{a}$ \\
2AP11 & $13.00 \mathrm{a}$ & $18.70 \mathrm{~b}$ & $13.90 \mathrm{a}$ \\
P19 16c & $11.93 \mathrm{a}$ & $17.00 \mathrm{c}$ & $12.60 \mathrm{a}$ \\
\hline
\end{tabular}

Averages followed by the same letter belong to the same group by the Scott-Knott test at 5\% probability level. NNF: Number of nodes in the main stem in flowering; NNM: Number of nodes at maturity; NNPROD: Number of productive nodes in the main stem.

Since the number of pods influences the grain yields per plant, taking into account traits NV1G, NV2G, the genotype 2AP11 has shown higher yield averages 5.30 and 44.20 for these respective traits. On the other hand, the genotypes TMG 2158 IPro and
2LP14 stand out for the NV3G, presenting averages of 25.93 and 25.40, respectively. Among the genotypes studied those that produced more pods were 2LP14, 2AP11, B2P15 and B2P28 with averages 98.9, 69.6, 78 and 81.8 , respectively (Table 4).

Table 4. Grain yield components and yielding of soybean lineages and cultivars cropped in the 2016/2017 harvest, Uberlândia-MG, Brazil.

\begin{tabular}{cccccc}
\hline Genotypes & NV1G & NV2G & NV3G & NVTt & PROD \\
\hline B2P1 & $2.40 \mathrm{~b}$ & 27.27 & $20.87 \mathrm{a}$ & $58.47 \mathrm{~b}$ & 4317.99 \\
B2P7 & $1.20 \mathrm{~b}$ & 13.70 & $19.20 \mathrm{a}$ & $48.60 \mathrm{~b}$ & 2831.71 \\
B2P8 & $2.47 \mathrm{~b}$ & 21.60 & $21.87 \mathrm{a}$ & $61.40 \mathrm{~b}$ & 4148.07 \\
B2P11 & $1.00 \mathrm{~b}$ & 22.00 & $6.20 \mathrm{~b}$ & $35.70 \mathrm{~b}$ & 2692.48 \\
B2P12 & $2.87 \mathrm{~b}$ & 25.47 & $10.73 \mathrm{~b}$ & $44.73 \mathrm{~b}$ & 3552.64
\end{tabular}


VIANNA, M. S. et al.

\begin{tabular}{cccccc} 
B2P13 & $1.10 \mathrm{~b}$ & 25.90 & $15.30 \mathrm{a}$ & $57.50 \mathrm{~b}$ & 3152.06 \\
B2P14 & $1.80 \mathrm{~b}$ & 25.87 & $6.47 \mathrm{~b}$ & $47.73 \mathrm{~b}$ & 1898.97 \\
B2P15 & $2.33 \mathrm{~b}$ & 39.60 & $18.53 \mathrm{a}$ & $78.00 \mathrm{a}$ & 4290.08 \\
B2P17 & $1.93 \mathrm{~b}$ & 29.33 & $10.53 \mathrm{~b}$ & $50.77 \mathrm{~b}$ & 2426.25 \\
B2P20 & $0.90 \mathrm{~b}$ & 14.00 & $4.70 \mathrm{~b}$ & $26.60 \mathrm{~b}$ & 2666.42 \\
B2P26 & $0.20 \mathrm{~b}$ & 25.70 & $5.80 \mathrm{~b}$ & $40.60 \mathrm{~b}$ & 2476.62 \\
B2P27 & $1.90 \mathrm{~b}$ & 29.93 & $16.88 \mathrm{a}$ & $62.30 \mathrm{~b}$ & 3555.93 \\
B2P28 & $4.40 \mathrm{a}$ & 35.70 & $21.10 \mathrm{a}$ & $81.80 \mathrm{a}$ & 3678.25 \\
B2P33 & $3.87 \mathrm{a}$ & 36.87 & $8.60 \mathrm{~b}$ & $53.20 \mathrm{~b}$ & 3423.82 \\
B2P38 & $3.67 \mathrm{a}$ & 32.87 & $7.73 \mathrm{~b}$ & $51.67 \mathrm{~b}$ & 2993.31 \\
B1P26 & $2.87 \mathrm{a}$ & 11.60 & $12.53 \mathrm{~b}$ & $35.00 \mathrm{~b}$ & 2098.51 \\
B1P33 & $3.33 \mathrm{a}$ & 28.53 & $15.40 \mathrm{a}$ & $54.07 \mathrm{~b}$ & 3848.92 \\
CD2737 & $0.27 \mathrm{~b}$ & 12.00 & $20.83 \mathrm{a}$ & $37.47 \mathrm{~b}$ & 4032.13 \\
TMG 2158 IPro & $0.40 \mathrm{~b}$ & 10.60 & $25.93 \mathrm{a}$ & $46.20 \mathrm{~b}$ & 4507.19 \\
2LP14 & $4.70 \mathrm{a}$ & 30.10 & $25.40 \mathrm{a}$ & $98.90 \mathrm{a}$ & 4785.63 \\
2AP11 & $5.30 \mathrm{a}$ & 44.20 & $6.60 \mathrm{~b}$ & $69.60 \mathrm{a}$ & 4240.11 \\
P1916c & $1.87 \mathrm{~b}$ & 22.07 & $12.93 \mathrm{~b}$ & $53.80 \mathrm{~b}$ & 3337.76 \\
\hline
\end{tabular}

Averages followed by the same letter belong to the same group by the Scott-Knott test at 5\% probability. NV1G: Number of pods with one grain; NV2G: Number of pods with two grains; NV3G: Number of pods with three grains; NTVt: Total number of pods. PROD: Yielding.

Increasing grain yield is one of the main objectives of soybean genetic breeding programs. In this study, genotype 2LP14 has shown larger yielding in comparison with other assessed genotypes, including controls CD2737 and TMG 2158 IPro. Among the 20 lines studied, 15 have presented yielding above the national average of $2882 \mathrm{~kg} \mathrm{~h}^{-1}$ (CONAB, 2017) (Table 4). Sediyama et al. (2015) claimed that cultivars are considered superior when its productivity is above $3000 \mathrm{~kg} \mathrm{ha}^{-1}$, therefore genotype P19 16c and all genotypes belonging to group 'a' were found productively superior.

Results present in Table 5, have shown that genotypic correlations were bigger than phenotypic correlations for most of the traits, which indicate that genetic factors have contributed more to these traits than the environmental ones (ALMEIDA; PELUZIO; AFFÉRRI, 2010). 
Table 5. Results of phenotypic correlation coefficients (rf) above the diagonal, and genotypic correlation coefficients (rg) below the diagonal, regarding 13 agronomic traits assessed in 20 lineages and 2 soybean cultivars, 2016/2017 harvest, Uberlândia- MG, Brazil.

\begin{tabular}{|c|c|c|c|c|c|c|c|c|c|c|c|c|}
\hline Caracteres & APF & NNF & APV & APM & NDM & NNPROD & NNM & NV1G & $\mathrm{NV} 2 \mathrm{G}$ & NV3G & $\mathrm{NTVt}$ & PROD \\
\hline NDF & $0,46^{*}$ & $0,59 *$ & 0,30 & 0,36 & 0,19 & $-0,18$ & 0,17 & 0,12 & 0,10 & $-0,14$ & 0,01 & $-0,19$ \\
\hline APF & & $0,89 *$ & $0,51^{*}$ & $0,68^{*}$ & 0,76 & $-0,15$ & 0,41 & $0,55^{*}$ & $0,62 *$ & $-0,49 *$ & 0,21 & $-0,33$ \\
\hline NNF & & & $0,44^{*}$ & $0,61^{*}$ & $0,73^{*}$ & $-0,08$ & $0,43^{*}$ & $0,67 *$ & $0,67 *$ & $-0,39$ & 0,38 & $-0,20$ \\
\hline APV & & & & $0,67 *$ & $0,50 *$ & 0,05 & $0,47^{*}$ & 0,02 & 0,15 & $-0,60^{*}$ & $-0,30$ & $-0,51 *$ \\
\hline APM & & & & & $0,51 *$ & 0,24 & $0,81 *$ & 0,33 & 0,3 & $-0,37$ & $-0,04$ & $-0,27$ \\
\hline NDM & & & & & & $-0,20$ & 0,35 & 0,36 & $0,62 *$ & $-0,49^{*}$ & 0,26 & $-0,27$ \\
\hline NNPROD & & & & & & & $0,52 *$ & 0,27 & 0,16 & 0,27 & 0,21 & 0,39 \\
\hline NNM & & & & & & & & 0,31 & 0,34 & $-0,18$ & 0,12 & $-0,06$ \\
\hline NV1G & & & & & & & & & $0,70 *$ & 0,03 & $0,66^{*}$ & 0,34 \\
\hline $\mathrm{NV} 2 \mathrm{G}$ & & & & & & & & & & $-0,19$ & $0,66^{*}$ & 0,26 \\
\hline NV3G & & & & & & & & & & & $0,52 *$ & $0,70 *$ \\
\hline NTVt & & & & & & & & & & & & $0,63^{*}$ \\
\hline
\end{tabular}

*: Significant at the $5 \%$ probability level by the $t$ test; +: significant to $5 \%$ by bootstrap with 5 thousand simulations; NDF and NDM: number of days to the flowering and at maturity; APF and APM: plant height at flowering and at maturity; NNF and NNM: Number of nodes at the flowering and at maturity; APV: first pod insertion height; NNPROD: number of productive

nodes in the main stem; NV1G, NV2G, NV3G: number of pods with one, two and three grains, respectively; NTVt: total of plant pods; PROD: grain yield. 
By evaluating correlations between agronomic traits in soybeans, Sousa et al. (2015) also have observed higher values of genotypic correlations about phenotype correlations to most of the evaluated traits, except plant height at flowering and plant height at maturity. Nogueira et al. (2012) and Leite et al. (2015) also observed higher genotypic correlations than phenotypic for agronomic traits assessed in soybean genotypes.

The plant height at flowering was correlated genetically and phenotypically with plant height at maturity, first pod insertion height and number of pods with one, two and three grains (Table 5). These correlations indicate that the higher one plant is when flowering, the higher this plant will be at maturity and also the insertion of its first pod, as well as larger will be the number of pods.

Plant height at flowering was positively correlated with plant height at maturity and first pod insertion height (Table 5). These correlations are important for breeding programs since plant height at maturity is a determining factor in the mechanized harvest. In this context, it is possible to perform indirect selection (SEDIYAMA; SILVA; BORÉM, 2015).

Phenotypic and genotypic correlations of grain yield concerning the total number of pods and the number of pods with three grains have presented extensive magnitude (Table 5), 0.62 and 0.81, therefore these traits are indicated for indirect selection. Alcântara Neto et al. (2014) applied pathway analysis to soybean yield and found similar results confirming that the number of pods per plant is the component of production having the greatest effect.

\section{CONCLUSIONS}

Traits related to the cycle, height and number of nodes in the main stem had shown ample magnitude for coefficients of genotypic determination and $\mathrm{CVg} / \mathrm{CVe}$ ratio, evidencing the possibility of successes in the selection of superior lineages in the Soybean Improvement Program of the Federal University of Uberlândia.

B2P1, B2P28, B1P33, and 2AP11 lineages stand out among genotypes showing superior grain yield and better agronomic traits.

The extensive magnitude of phenotypic and genotypic correlations between the grain yield and the number of pods with three grains and the number of total pods have evidenced the possibility of indirect selection aiming grain yield increases.

\section{ACKNOWLEDGMENTS}

To the Foundation for Research Support of the State of Minas Gerais (Fundação de Amparo à Pesquisa do Estado de Minas Gerais - FAPEMIG) for granting the first author's scholarship.

RESUMO: A soja é uma cultivar de grande importância econômica mundial e por esse motivo essa leguminosa é explorada nos programas de melhoramento, que visam disponibilizar cultivares de alta produtividade de grãos, tolerantes a pragas e doenças e adaptadas à diferentes condições edafoclimáticas. Os objetivos desse trabalho foram selecionar linhagens, avaliar parâmetros genéticos e correlações entre caracteres de soja. O experimento foi conduzido na área experimental da Fazenda Capim Branco pertencente à Universidade Federal de Uberlândia na safra de 2016/2017. Avaliaram-se 22 genótipos em delineamento de blocos completos casualizados com três repetições para 15 caracteres morfo-agronômicos. Os caracteres agronômicos relacionados ao ciclo, altura, número de nós e vagens totais tiveram coeficiente de determinação genotípico superiores a $70 \%$. Obteve-se coeficiente de variação para o caráter número de dias para o florescimento igual a 3,79\% e para o caráter número de dias para maturação, 4,87\%, indicando maior homogeneidade entre os dados e baixa variação ao acaso. Dos caracteres avaliados, dez apresentaram razão entre coeficiente de variação genético e coeficiente de variação ambiental superiores a um, demonstrando oportunidade de sucesso no processo de seleção para esses respectivos caracteres. 15 genótipos obtiveram produtividade de grãos superior à média nacional de safra 2016/2017, isto é, a $2882 \mathrm{~kg} \mathrm{~h}^{-1}$. As correlações fenotípicas entre caracteres que foram significativas oscilaram de $-0,49$ a 0,89 , cujas estimativas de correlação genotípica foram superiores à correlação fenotípica, indicando que os fatores genéticos contribuíram mais que 
os ambientais. Os caracteres relacionados ao ciclo, altura e número de nós na haste principal, tiveram $\mathrm{H}^{2}$ de elevada magnitude e altas estimativas na razão $\mathrm{CVg} / \mathrm{CVe}$, evidenciando a possibilidade de seleção de linhagens superiores no Programa de Melhoramento de Soja da Universidade Federal de Uberlândia. Considerando o caráter produtividade de grãos, foi possível identificar número de vagens de três grãos e número total de vagens para a seleção indireta, com base nas correlações fenotípicas e genotípicas. As linhagens 21P14, B2P1, B2P28, B1P33 e 2AP11 destacam-se como genótipos superiores na seleção direta.

PALAVRAS-CHAVE: Glycine max. Melhoramento genético. Seleção indireta.

\section{REFERENCES}

ALMEIDA, L. A.; R. A. S. KIIHL. Melhoramento da soja no Brasil - desafios e perspectivas. In: SOJA: TECNOLOGIA E PRODUÇÃO. Gil. M. S. Câmara (ed.). Piracicaba, SP, USP-ESALQ, 1998, p. 40-54.

ALMEIDA, R. P.; PELÚZIO, J.M.; AFERRI, F. S. Correlações fenotípicas, genotípicas e ambientais em soja cultivada sob condições várzea irrigada, sul do Tocantins. Bioscience Journal, Uberlândia, v. 26, n. 1, p. 9599, 2010. https://doi.org/10.1590/s1806-66902011000100014

ALMEIDA, R. D.; PELÚZIO, J. M.; AFFÉRRI, F. S. Divergência genética entre cultivares de soja, sob condições de várzea irrigada, no sul do Estado Tocantins. Revista Ciência Agronômica, Fortaleza, v. 42, n. 1, p. 108-115, 2011. https://doi.org/10.1590/s1806-66902011000100014

AMORIM, F. A.; HAMAWAKI, O. T.; SOUSA, L. B.; LANA, R. M.; HAMAWAKI, C. D. L. Época de semeadura no Potencial Produtivo de Soja em Uberlândia-MG. Semina: Ciências Agrárias, Londrina, v. 32, n. 1, p. 1793-1802, 2011. https://doi.org/10.5433/1679-0359.2011v32suplp1793

ANDRADE, A. C. B.; SILVA, A. J.; FERRAUDO, A. S.; UNÊDA-TREVISOLI, S. H.; DI MAURO, A. O. Strategies for selecting soybean genotypes using mixed models and multivariate approach. African Journal of Agricultural Research, v. 11, n. 1, p. 23-31, 2016.

BARROS, J. P. A.; SEDIYAMA, T.; SILVA, F. C. S.; SILVA, A. F.; BEZERRA, A. R. G.; ROSA, D. P.; SILVA, A. L.; OLIVEIRA, D. S. Estimates of genetic parameters and efficiency in selection for branching capacity in soybean genotypes. Journal of Agronomy, Falsalabad, v. 15, n. 1, p. 39-44, 2016.

https://doi.org/10.3923/ja.2016.39.44

BEZERRA, A. R. G. Botânica e Fenologia. In: SEDIYAMA, T.; SILVA, F. Soja do plantio a colheita ( ${ }^{\circ}$ ed.) Editora UFV, 2015. P. 27-53.

BONETTI, L. P. Cultivares e seu melhoramento genético. In: VERNETTI, F.J. (Ed.) Soja: genética e melhoramento. Fundação Cargill, Campinas, p. 741-800, 1983.

BORÉM, A. Importância econômica. In: SEDIYAMA, T.; SILVA, F (1º ed.) Soja: do plantio à colheita. UFV, Viçosa, 2015. p. 09-26.

COMPANHIA NACIONAL DE ABASTECIMENTO - CONAB. Acompanhamento da safra brasileira: grãos: primeiro levantamento, outubro, 2016. Brasília: CONAB, 2016. Disponível em http://www.conab.gov.br. Acesso em: 1 out. 2016. https://doi.org/10.11606/t.11.2014.tde-05052014-105819 
CRUZ, C. D.; REGAZZI, A. J.; CARNEIRO, P. C. S. Modelos biométricos aplicados ao melhoramento genético. Viçosa, MG: UFV, 2012. v. 1, 514 p.

CRUZ, C. D. Genes: a software package for analysis in experimental statistics and quantitative genetics. Acta Scientiarum, Agronomy, v. 35, n. 3, p. 271-276, 2016.

CUNHA, M. C. G.; HAMAWAKI, O. T.; SOUSA, L. B. Genetic variability among 79 soybean progenies from UFU breeding program. Bioscience Journal, Uberlândia, v. 29, n. 2, p. 340-349, 2013.

DALCHIAVON, F. C.; PASSOS E CARVALHO, M. Correlação linear e espacial dos componentes de produção e produtividade da soja. Semina: Ciências Agrárias. Londrina: Universidade Estadual de Londrina (UEL), v. 33, n. 2, p. 541-552, 2012. Disponível em: <http://hdl.handle.net/11449/10329>. Acesso em 12 de maio de 2017. http://doi.org/10.5433/1679-0359.2012v33n2p541

DALLASTRA, A.; UNÊDA-TREVISOLI, S. H..; FERRAUDO, A. S.; DI MAURO, A. O. Multivariate approach in the selection of superior soybean progeny which carry the RR gene. Revista Ciência Agronômica, Fortaleza, v. 45, n. 3, p. 588-597, 2014. https://doi.org/10.1590/s1806-66902014000300021

DORNELES, L. M. C.; REZENDE, D. F.; SOUSA, L. B.; HAMAWAKI, O. T Diversidade genética entre linhagens de soja semiprecoce no município de Goiatuba - GO, safra 2009/2010. Revista Verde, Mossoró, v.6, n.1, p. 22-27, 2011.

EMPRESA BRASILEIRADE PESQUISA AGROPECUÁRIA - EMBRAPA. Ministério da Agricultura Pecuária e abastecimento. Soja Transferência e Tecnologia. Cultivares de Soja-Regiões Sul e Central do Brasil 2010/2011. Londrina, Paraná, 2010.

EMPRESA BRASILEIRA DE PESQUISA AGROPCECUÁRIA (EMBRAPA). Tecnologias de produção de soja - Região Central do Brasil 2014. Sistemas de Produção. Embrapa Soja. Londrina: Embrapa Soja, 2013. 265p. https://doi.org/10.21475/ajcs.19.13.01.p1109

EMPRESA BRASILEIRADE PESQUISA AGROPECUÁRIA (EMBRAPA). Embrapa soja. Londrina, Paraná. Disponível em: < https://www.embrapa.br/soja/cultivos/soja1/dados-economicos $>$. Acesso em: 21 de abril de 2017. https://doi.org/10.21475/ajcs.19.13.01.p1109

FALCONER, D. S.; MACKAY, T. F. C. Introduction to quantitative genetics, 4.ed. Longmans Green, Harlow, Essex, UK, 1996, 464p.

FAO, Food and Agriculture Organisation. OECD/FAO (2015), "Panorama Agrícola OECD-FAO", estatísticas agrícolas da OECD (base de dados). Disponível em: $<$ dx.doi.org/10,1787/agr-outldata-em $>$ Acesso em 21 de abril 2017. https://doi.org/10.1787/agr_outlook-2015-4-es

FEHR, W. R.; CAVINESS, C. E. Estate of soybean development. Ames: Iowa State University of Science and Technology, 1977. $11 \mathrm{p}$.

FELICI, P. H. N.; HAMAWAKI, O. T. UFUS Mineira: nova cultivar de soja para o estado de Minas Gerais. Bioscience Journal, Uberlândia, v. 26, n. 3, p. 424-427, 2010. https://doi.org/10.1590/s0100204x2007000100020 
FREITAS, M. de. C. M. A Cultura da soja no Brasil: o crescimento da produção brasileira e o surgimento de uma nova fronteira agrícola. Enciclopédia Biosfera, Centro Científico Conhecer, Goiânia - GO. v. 7, n. 12, 2011.

GARCIA, R. A.; CESAR, J. F. Avaliação da resistência da soja a Sclerotinia sclerotiorum em diferentes estádios fenológicos e períodos de exposição ao inóculo. Tropical Plant Pathology, Uberlândia, v. 37, p. 196-203, 2012. https://doi.org/10.1590/s1982-56762012000300006

GLASENAPP, J. S.; SEDIYAMA, T.; CRUZ, C. D.; MATSUO, E.; BROMMONSCHENKEL, S. H.; OLIVEIRA, R. C. T.; HAMAWAKI, O. T. Diversidade de características agronômicas e moleculares em cultivares de soja com diferentes graus de resistência à Phakopsora pachyrhizi. Bioscience Journal, Uberlândia, v. 31, n. 1, p. 25-36, 2015. https://doi.org/10.14393/bj-v31n1a2015-171666

INSTITUTO BRASILEIRO DE GEOGRAFIA E ESTATÍSTICA - IBGE. Pesquisa Mensal de Previsão e Acompanhamento das Safras Agrícolas no Ano Civil. Levantamento Sistemático da Produção Agrícola Dezembro 2011 (p. 33 e p. 40). Disponível em: < IBGE - Grupo de Coordenação de Estatísticas Agropecuárias - GCEA/IBGE, DPE, COAGRO - Levantamento Sistemático da Produção Agrícola, fevereiro 2012>. Acesso em 10 de abril de 2017. https://doi.org/10.17143/ciaed/xxiilciaed.2017.00322

JUNIOR, J. A. F.; UNÊDA-TREVISOLI, S. H.; ESPÍNDOLA, S. M. C. G.; VIANNA, V. F.; DI MAURO, A. O. Diversidade genética em linhagens avançadas de soja oriundas de cruzamentos biparentais, quádruplos e óctuplos. Revista Ciência Agronômica, Fortaleza, v. 46, n. 2, p. 339-351, 2015.

LEITE, W. S.; PAVAN, B. E.; FILHO, C. H. A. M.; NETO, F. A.; OLIVEIRA, C. B.; FEITOSA, F. S. Estimativas de parâmetros genéticos e correlações entre caracteres agronômicos em genótipos de soja. Nativa, Sinop, v. 3, n. 4, p. 241-245, 2015. https://doi.org/10.14583/2318-7670.v03n04a03 LEMES, Ernani; HUMBERTO, Leonardo C.; ASSIS, Rafael T. Doenças da Soja: Melhoramento Genético e técnica de manejo. Millennium Editora, Campinas, SP. 2015.

LOPES, A. C. A.; PANDINI, F.; ROCHA, M. M.; TSUTSUMI, Y. Variabilidade e correlações entre caracteres em cruzamentos de soja Scientia Agricola, Piracicaba, v. 59 n. 2 p. 341-348, 2002. https://doi.org/10.1590/s0103-90162002000200021

LUDWIG, M. P.; DUTRA, L. M. C.; FILHO, O. A L.; ZABOT, L.; UHRY, A. J. D. Populações de plantas na cultura da soja em cultivares convencionais e Roundup Read. Revista Ceres, Viçosa, v. 58, n. 3, p. 305-313, 2011. https://doi.org/10.1590/s0034-737x2011000300010

MACHIKOWA, T.; LAOSUWAN, P.; Path coefficient analysis for yield of early maturing soybean. Songklanakarin J. Sci. Technol; v. 33, ed. 4, p. 365-368, 2011.

MANTOVANI, E. C.; ZAMBOLIM, L.; SOUZA, D. O.; SEDIYAMA, G. C.; PALARETTI, L. F.; Produtividade e qualidade de tubérculos de batata sob diferentes regimes de irrigação por aspersão convencional. Horticultura Brasileira, v. 31, p. 528- 533, 2013. https://doi.org/10.1590/s010205362013000400004 
MARCONATO, M. B. Diversidade fenotípica por meio de caracteres agronômicos em acessos de soja. 2014. 61 f. tes (Mestrado) - Curso de Agronomia, Universidade Estadual Paulista, Jaboticabal, 2014. https://doi.org/10.17138/tgft(2)133-135

MARTINS, J. D.; RADONS, S. Z.; STRECK, N. A.; KNIES, A. E.; CARLESSO, R. Plastocrono e número final de nós de cultivares de soja em função da época de semeadura. Ciência Rural, Santa Maria, v. 41, n. 6, p. 954-959, 2011. https://doi.org/10.1590/s0103-84782011005000064

MULLER, L. Taxionomia e morfologia. In: MIYASAKA, S.; MEDINA, J. C. (Eds). A soja no Brasil. Campinas: Instituto de Tecnologia de Alimentos, 1981. p.65-104.

NETO, F. A.; GRAVINA, G. A. MONTEIRO, M. M. S.; MORAIS, F. B.; PETTER, F. A.; ALBUQUERUQE, J. A. A. Análise de trilha do rendimento de grãos de soja na microrregião do Alto Médio Gurguéia. Comunicata Scientiae, Bom Jesus, v. 2, n. 2, p. 107-112, 2011.

NOGUEIRA, A. P. O. Morfologia, crescimento e desenvolvimento. In: SEDIYAMA, T. (Ed). Tecnologias de produção e usos da soja. Londrina: Mecenas, 2009, 7-16p.

NOGUEIRA, A. P. O., Correlações entre caracteres e análise de trilha em soja cultivada em duas épocas de semeadura. 2011. Tese (Doutorado em Genética e Melhoramento). Universidade Federal de Viçosa, Janeiro, 2011. https://doi.org/10.11606/d.11.2018.tde-20181127-160703

NOGUEIRA, A. P. O.; SEDIYAMA, T.; SOUSA, L. B.; HAMAWAKI, O. T.; CREUZ, C. D.; PEREIRA, D. G.; MATSUO, E. Análise de trilha e correlações entre caracteres em soja cultivada em duas épocas de semeadura. Bioscience Journal, Uberlândia, v. 28, n. 6, p. 877-888, 2012.

https://doi.org/10.11606/d.11.2018.tde-20181127-160703

NOGUEIRA, A. P. O. Estádio de desenvolvimento. In SEDIYAMA, T. Tecnologias de produção de sementes de soja. Londrina Mecenas, 2013, p. 15-44.

NOGUEIRA, A. P. O; SEDIYAMA, T.; GOMES, J.D. Avanços no melhoramento genético da cultura da soja nas últimas décadas. In: LEMES, E; CASTRO, L.; ASSIS, R. (Org.) Doenças da soja: Melhoramento Genético e Téenicas de Manejo. Campinas: Millennium Editora, 2015, p. 159-178. https://doi.org/10.11606/t.11.2008.tde-17072008-173405

PERINI, L.; JUNIOR, N. S. F.; DESTRO, D.; PRETE, C. E. C. Componentes da produção em cultivares de soja com crescimento determinado e indeterminado. Semina: Ciências Agrárias, Londrina, v. 33, n. 1, p. 2531- 2544, 2012. https://doi.org/10.5433/1679-0359.2012v33Supl1p2531

PIMENTEL, A. J. B.; RIBEIRO, G.; SOUZA, M. A.; MOURA, L. M.; ASSIS, J. C.; MACHADO, J. C. Comparação de métodos de seleção de genitores e populações segregantes aplicados ao melhoramento de trigo. Bragantia, Campinas, v. 72, n. 2, p. 113- 121, 2013. https://doi.org/10.1590/S0006-87052013005000026

PIRES, L. P. M.; PELUZIO, J. M.; CANCELLIER, L. L.; RIBEIRO,G. R.; COLOMBO, G. A.; AFFÉRRI, F, S. Desempenho de genótipos de soja, cultivados na região centro-sul do estado do Tocantins, safra 2009/2010.

Bioscience Journal, Uberlândia, v. 28, n. 2, p. 214-223, 2012. 
PROGRAMA DE MELHORAMENTO DE SOJA. Disponível em:

$<$ http://www.dag.uem.br/pet/home/MelhoramentoSoja.pdfs. Acesso em: 30 de Abril de 2017.

RAHMAN, M. M.; HOSSAIN, M. M. Plant density effects on growth, yield and yield components of two soybean varieties under equidistant planting arrangement. Asian Journal of Plant Sciences, v. 10, n. 5, p, 278-286, 2011. https://doi.org/10.3923/ajps.2011.278.286

RODRIGUES, B.; SERAFIM, F.; NOGUEIRA, A. P. O.; SOUSA, L. B.; HAMAWAKI, O. T. Correlations between traits in soybean (Glycine max L.) naturally infected with Asian rust (Phakopsora pachyrhizi).

Genetics and Molecular Research, Ribeirão Preto, v. 14, n. 4, p. 17718-17729, 2015.

https://doi.org/10.4238/2015.December.21.45

ROMANATO, F. N. Correlação, adaptabilidade e estabilidade de genótipos de soja. Uberlândia, 2013.

62. Dissertação (Mestrado em Agronomia - Fitotecnia) - Instituto de Ciências Agrárias, Universidade Federa de Uberlândia, 2013.

SALIMI, S.; MORADI, S. Effect the Correlation, Regression and Path Analysis in Soybean Genotypes (Glycine max L.) under Moisture and normal condition. Journal of Agronomy and Plant Production, Tehran, v. 3, n. 10, p. 447-454, 2012.

SEDIYAMA. T. Tecnologias de produção e usos da soja. Londrina: Mecenas, 2009.

SEDIYAMA, T.; TEIXEIRA, R. C.; BARROS, H. B. Origem, evolução e importância econômica. In: SEDIYAMA, T. (Ed.). Tecnologias de produção e usos da soja. Londrina: Mecenas, 2009, p. 1-5.

SEDIYAMA, T. Importância econômica da semente. In: SEDIYAMA, T. Tecnologias de produção e usos da soja. Londrina: Mecenas Ltda, 2013. Cap. 1. p. 11.

SEDIYAMA, T.; TEIXEIRA, R de C.; REIS, M. S. Melhoramento da Soja. In: BORÉM, A. (Ed.). Melhoramento de espécies cultivadas. Viçosa: UFV, 2015. p. 553- 604.

SEDIYAMA, T.; SILVA, F.; BORÉM, A. Soja: do plantio à colheita. Viçosa, MG: UFV, 2015, 333p.

SEDIYAMA, T.; OLIVEIRA, R. C. T.; SEDIYAMA, H. A. A soja. In: SEDIYAMA, T. (Ed.) Produtividade da Soja. Mecenas: Londrina, 2016, p. 11-18.

SILVA, A. F.; SEDIYAMA, T.; BORÉM, A.; SILVA, F. C. S. Cultivares. In: SEDIYAMA, T.; SILVA, F.; BORÉM, A.; (Eds). Soja do plantio à colheita. Viçosa: UFV, 2015, 149-167p.

SOUSA, L. B.; Diversidade fenotípica e molecular, correlações entre caracteres, adaptabilidade e estabilidade de genótipos de soja. Tese de Doutorado em Melhoramento Genético Vegetal - Instituto de Ciências Agrárias Universidade Federal de Uberlândia, julho 2013.

SOUSA, L. B.; JUNIOR, C. D. S.; HAMAWAKI, O. T.; HAMAWAKI, C. D. L. Correlation between yield components in f6 soybean progenies derived from seven biparental crosses. Bioscience Journal, Uberlândia, v. 31, n. 6, p. 1692-1699, 2015. https://doi.org/10.14393/BJ-v31n6a2015-26217 
UNÊDA-TREVISOLI, S.H.; CARDOSO, G. K. R.; DI MAURO, A. O.; BLAT, S. F.; BÁRBARO, I. M.; BALDIN, J. P.; NASCIMENTO, A. F. Avaliação de cultivares de soja precoces para cultivo em áreas de reforma de cana-de-açúcar. Ciência e Tecnologia, Jaboticabal, v. 1, n. 1, p. 50-57, 2010.

VIANNA, V. F., UNÊDA-TREVISOLI, S. H.; DESIDERIO, J. A.; SANTIAGO, S.; CHARNAI, K.; JUNIOR, J. A. F.; FERRAUDO, A. S.; DI MAURO, A. O. The multivariate approach and influence of characters in selecting superior soybean genotypes. African Journal of Agricultural Research, v. 8, n. 30, p. 4162-4169, 2013.

VITTI, G. C.; TREVISAN, W. Manejo de Macro e Micronutrientes para alta produtividade da soja. Departamento de Solos e Nutrição de Plantas, ESALQ/USP. Informações agronômicas Nº 90, 2000. 